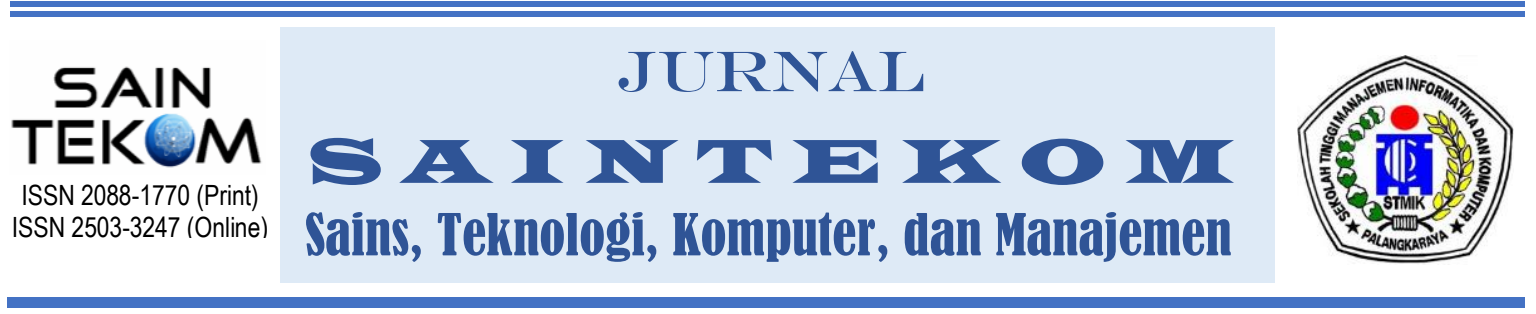

\title{
RANCANG BANGUN SISTEM INFORMASI RETENSI REKAM MEDIS DI RSIA X
}

\author{
*Ramti Kania Putri ${ }^{1}$, Yuda Syahidin ${ }^{2}$, Meira Hidayati ${ }^{3}$ \\ ${ }^{1,2)}$ Program Studi Informatika Rekam Medis Politeknik Piksi Ganesha \\ 3)Program Studi Rekam Medis dan Informasi Kesehatan Politeknik Piksi Ganesha \\ Jl. Jend. Gatot Subroto 301 Bandung \\ Email: rkputri3@piksi.ac.id, yuda.syahidin@piksi.ac.id, \\ meira.hidayati@piksi.ac.id
}

\begin{abstract}
This study aimed to design and create an outpatient medical record retention information system at The $X$ Hospital. The results of research conducted, found several problems faced by the health center. It's hard to find active and inactive medical record data, so the medical record data that are retained or inactive is unknown. The research method used is a qualitative approach that is supported by data collection techniques, using observation, interviews, and library research. The development method used is the waterfall method assisted by the design of Data Flow Diagrams. This system is based on a desktop that uses Microsoft Visual Studio 2010 as a programming language and uses the Microsoft Office Access 2013 database. Based on the problems above, the writer tries to give some suggestions, including (1) the Need development of information systems technology that the author will design. (2) Integration of health information systems to obtain efficient and effective performance.
\end{abstract}

Keywords: Medical record retention, Retention system, System design

\begin{abstract}
ABSTRAK
Penelitian ini bertujuan untuk merancang dan membuat sistem informasi Retensi Rekam Medis di Rumah Sakit Ibu dan Anak X. Hasil penelitian yang dilakukan, ditemukan beberapa masalah yang dihadapi oleh pihak Rumah sakit. Sulitnya menemukan data Rekam medis yang Aktif dan Inaktif, sehingga data Rekam medis yang di Retensi atau di Inaktif sulit diketahui. Metode penelitian yang digunakan merupakan pendekatan Kualitatif yang didukung oleh teknik pengumpulan data dengan cara observasi, wawancara dan studi pustaka. Metode pengembangan yang digunakan adalah metode waterfall yang dibantu oleh perancangan Data Flow Diagram. Sistem ini dibuat dengan berbasis desktop yang menggunakan Microsoft Visual Studio 2010 sebagai bahasa pemrograman dan menggunakan Database Microsoft Office Access 2007. Berdasarkan permasalahan di atas, maka penulis memberikan beberapa saran diantaranya adalah: (1) Perlu adanya pengembangan teknologi sistem informasi yang akan penulis rancang, (2) Intergrasi sistem informasi kesehatan guna mendapatkan kinerja yang efesien dan efektif.
\end{abstract}

Kata kunci: Perancangan sistem , Retensi rekam medis, Sistem Retensi 


\section{PENDAHULUAN}

Salah satu hal yang terpenting di dunia yaitu Kesehatan, Kesehatan tidak bisa dipisahkan dengan apa yang disebut Rumah Sakit, Rumah sakit merupakan fasilitas pelayanan kesehatan memberikan pelayanan medis, selain itu Rumah Sakit juga dituntut untuk menyediakan informasi kesehatan yang dibutuhkan, dimana setiap unsur kesehatan di dalamnya. Dan sebaliknya rasa sakit adalah suatu hal yang di upayakan berkurang dalam waktu singkat, karena menjadi sehat adalah tujuan dari semua orang yang datang ke Rumah sakit. Semua hal yang berkaitan dengan sehat dan sakit tertuang dalam kumpulan berkas-berkas atau formulir-formulir yang disatukan dalam suatu dokumen yang dinamakan Rekam Medis. pengelolaan rekam medis berkaitan dengan pengelolaan rekam medis antara lain Assembling, Coding, Indexing, Filling, serta retensi dan pemusnahan (Erawantini, 2017) Di Rumah Sakit tentunya sudah banyak yang memiliki "Sistem informasi Rekam medis" yang sudah terpadu.

Sistem informasi rekam medis filing mempermudah petugas dalam mengontrol dokumen rekam medis di filing melalui peminjaman, pengembalian serta retensi (Farlinda, 2019)

Upaya yang dilakukan pemerintah untuk perkembangan meningkatkan kualitas pelayanan Rumah sakit di antaranya Rekam medis. Rekam medis adalah berkas berisikan catatan dan dokumen antara lain identifikasi pasien, hasil pemeriksaan, pengobatan yang telah diberikan kepada pasien. Rekam medis harus dibuat secara tertulis, lengkap, dan jelas atau secara elektronik(PERMENKES, 2008).

Electronic medical record(EMR) sering dipertukarkan dengan computerbased patient record (CPR) untuk menyatakan suatu sistem berbasis komputer yang dimanfaatkan untuk mengelola informasi pelayanan pasien (Sudirahayu, 2016).

Semakin bertambah jumlah Rekam medis di Rumah sakit, maka dari itu tidak selamanya Rekam medis dalam rak penyimpanan akan disimpan selamanya dikarenakan ruang penyimpanan akan semakin penuh dan tidak cukup ruang lagi untuk Rekam medis baru. Upaya yang ditempuh untuk menyelesaikan permasalahan tersebut adalah dengan pemusnahan berkas Rekam medis. Pelaksanaan pemusnahan berkas rekam medis harus 
sesuai SPO (Standar Prosedur Operasional) tentang pelaksanaan Retensi dan pemusnahan berkas rekam medis pasien untuk membantu kelancaran proses Retensi, memudahkan mengolah penyimpanan file aktif dan InAktif. Hal ini sejalan dengan penelitian (Hariyanti, 2018) menyatakan bahwa pemusnahan berkas rekam medis untuk membantu kelancaran kegiatan retensi.

Rekam medis juga harus disimpan sesuai dengan peraturan yang ada, untuk sarana pelayanan kesehatan di Rumah sakit, Rekam medis rawat inap harus disimpan sekurangkurangnya 5 Tahun sejak pasien berobat terakhir di Rumah sakit. Setelah 5 Tahun, Rekam medis dapat dimusnahkan kecuali Ringkasan pasien dan lembar persetujuan tindakan medik. Retensi yaitu kegiatan pengurangan atau pemisahan arsip dari rak penyimpanan. Retensi atau yang disebut penyusutan merupakan kegiatan memisahkan Rekam medis Aktif dan Rekam medis Inactive, serta pengurangan jumlah formulir yang terdapat di dalam berkas Rekam medis dengan cara memilah nilai guna dari tiap-tiap formulir seperti berkas Resume, Informed Consent, Lembar operasi, Lembar kematian, Lembar Identitas bayi lembar yang memiliki nilai guna akan disimpan dan di scanner sedangkan dokumen Rekam medis yang tidak memiliki nilai guna ditumpuk di dokumen Rekam medis Inactive akan Dilakukan pemusnahan (Saraswati, 2015).

Berdasarkan penelitian yang dilakukan di Unit Rekam medis RSIA X melalui Observasi dan Wawancara petugas Rekam medis bahwa RSIA X sudah melakukan 1 kali Retensi dan pada saat melakukan Retensi terdapat beberapa kendala seperti kurangnya sumber daya manusia, waktu dan berkas dokumen Rekam medis yang belum di Retensi. Lalu dalam tempat penyimpanan berkas InAktif tidak ada ruangan tersendiri masih menyatu dengan tempat penyimpanan berkas yang masih Aktif.

Proses pendataan berkas Rekam medis yang telah di Retensi di RSIA X masih menggunakan Microsoft Excel, hal ini kurang Efektif karena apabila dibutuhkan membutuhkan waktu, selain itu juga jika dihubungkan dengan kemajuan Teknologi maka dapat meningkatkan mutu pelayanan yang baik. Maka dari itu tujuan dari penelitian ini adalah Perancangan 
sistem informasi Retensi Rekam medis menggunakan Microsoft Visual Studio 2010 di RSIA X.

\section{METODE}

\section{Metodologi}

Penelitian merupakan cara ilmiah untuk mendapatkan data dengan tujuan dan kegunaan tertentu (Sugiyono, 2018). Metodologi penelitian yang digunakan dalam penelitian ini adalah metode penelitian Kualitatif dengan menggunakan pendekatan Deskriptif yaitu mendeskripsikan atau menggambarkan fenomena-fenomena yang belum ada di lapangan, baik yang bersifat alamiah ataupun yang bersifat rekayasa manusia. Subjek penelitian petugas khusus dan petugas bagian filing yang melakukan Retensi di RSIA X. Objek penelitian pelaksanaan Retensi berkas Rekam medis Aktif ke InAktif dan program sistem informasi Retensi.

Pengumpulan data pada penelitian ini dengan cara Observasi, Wawancara, catatan Laporan dan meminta data dokumen-dokumen lainnya di bagian Rekam medis khususnya tentang pemanfaatan sistem informasi Retensi Rawat inap di RSIA $X$. Metode pengembangan perangkat lunak yang digunakan peneliti yaitu
Metode Waterfall, Model waterfall adalah model klasik yang bersifat sistematis, berurutan dalam membangun software. Nama model ini sebenarnya adalah "Linear Sequential Model". Model ini sering disebut juga dengan "classic lifecycle" atau metode waterfall (Pressman, 2015) di tunjukan Pada gambar 1 ini adalah Tahapan pengembangan Waterfall.

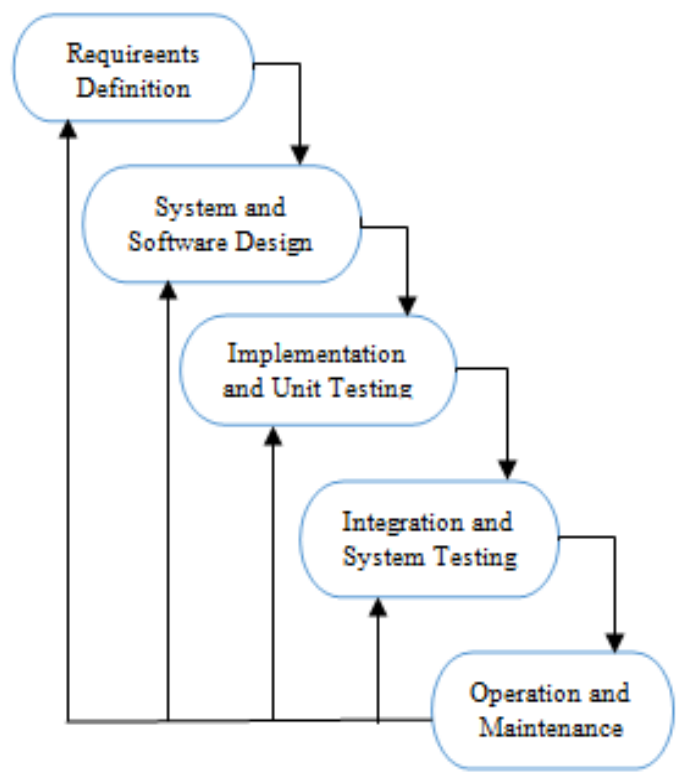

Gambar 1. Tahapan Metode pengembangan Waterfall ( Sumber : Pressman, 2015)

Pada Gambar 1 menggambarkan Tahapan Metode Waterfall mencerminkan kepraktisan model proses perangkat lunak dalam pengembangan sistem perangkat lunak dan hardware yang luas.

Flowmap adalah pengembangan secara grafik dari langkah-langkah dan 
urutan-urutan prosedur dari suatu program seperti pada gambar 5.

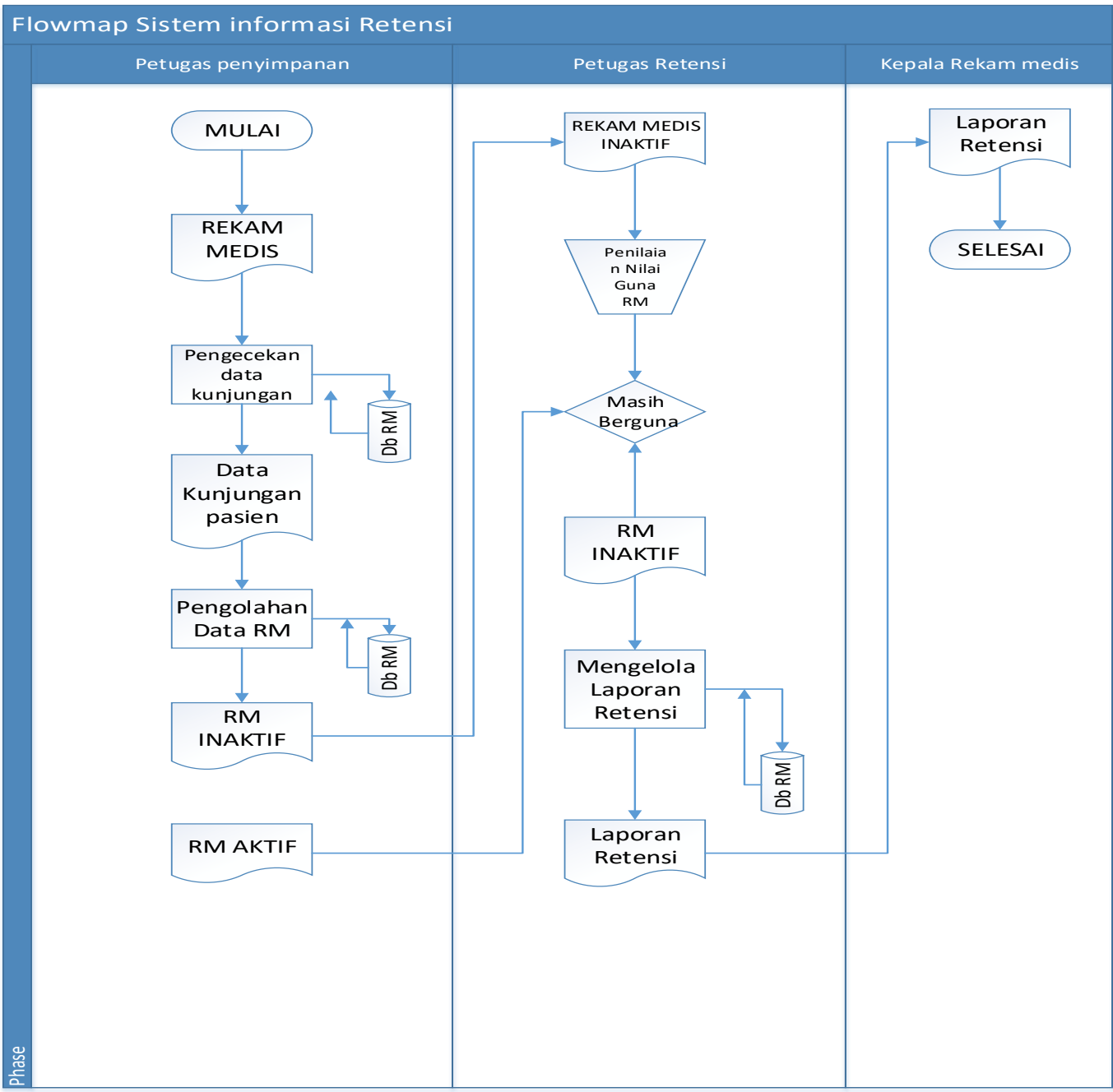

Gambar 5. Flowmap yang sedang dirancang

Pada Gambar 5. Merupakan

Flowmap yang dirancang dari mulai sampai dengan selesai Berkas RM diretensi

A. Rancangan sistem yang
Diagram konteks adalah salah satu level ada di data flow, pada gambar

6.

\section{dikembangkan}

\section{Diagram Konteks}




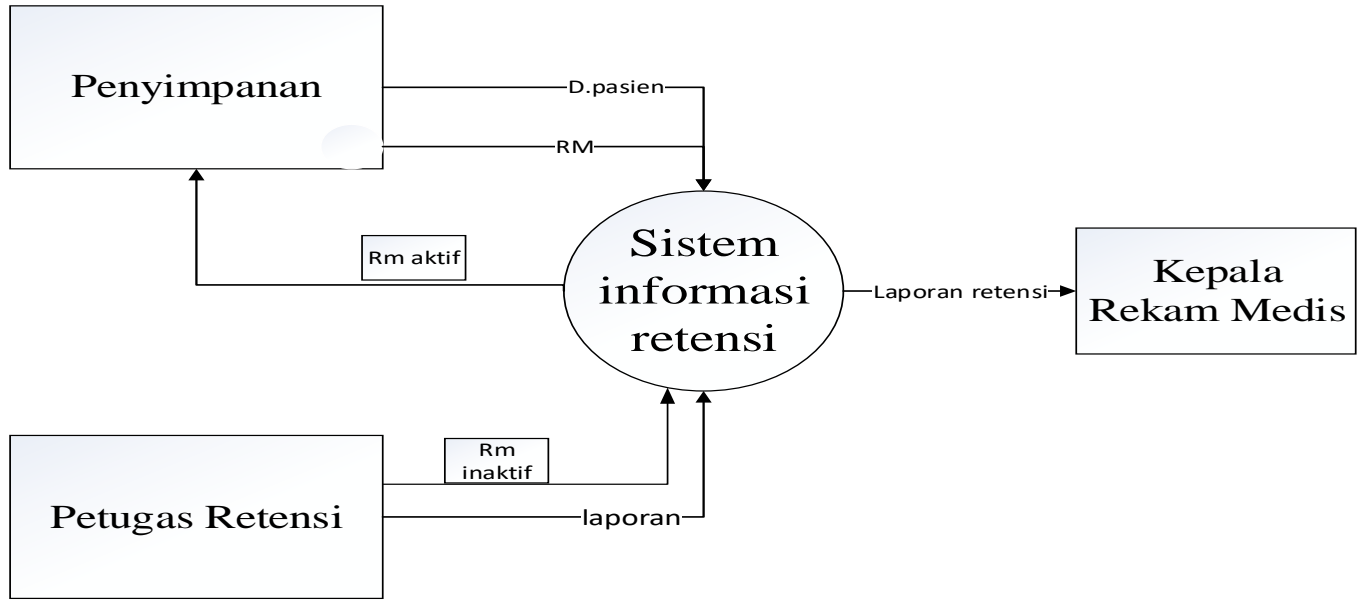

Gambar 6. Diagram Konteks yang diusulkan

Gambar 6 menggambarkan rancangan alur sistem retensi antara petugas rekam medis, kepala rekam dan di sampaikan laporannya ke kepala Rumah Sakit.

\section{Data Flow Diagram (DFD) mengenai input dan output.} yang diusulkan
DFD adalah suatu diagram yang menggambarkan aliran data dari sebuah proses yang sering disebut dengan sistem informasi. Di dalam data flow diagram juga menyediakan informasi

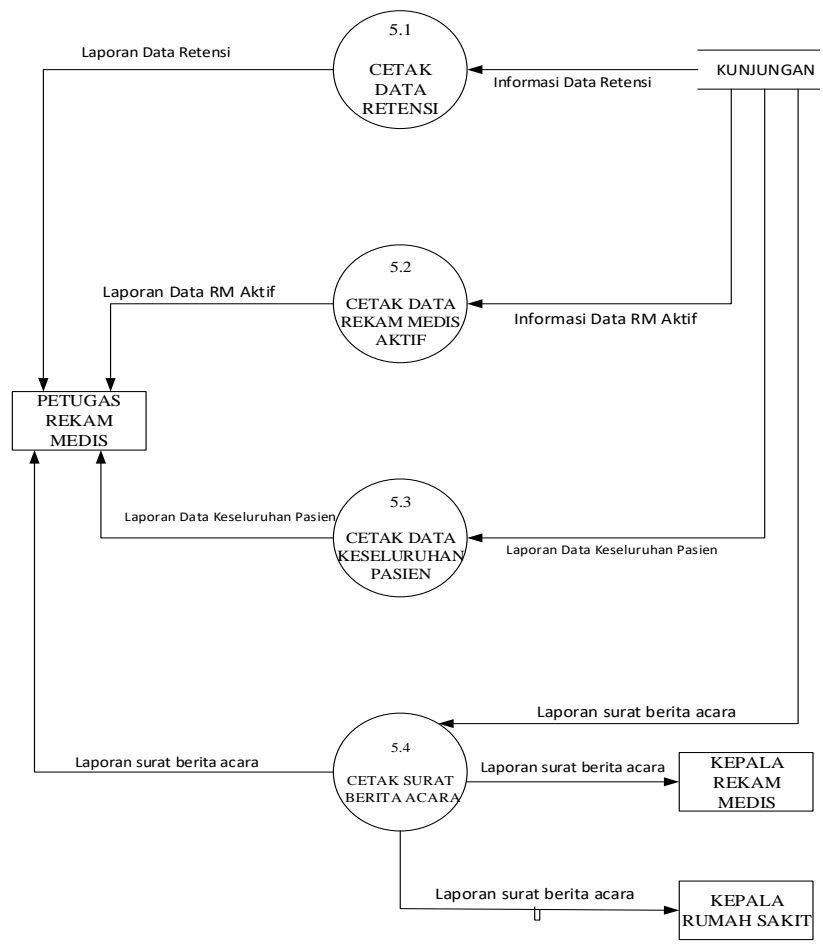

Gambar 7. Data Flow Diagram 
3. EntityRelationship Diagram

ERD merupakan model untuk menyusun database agar dapat menggambarkan data yang mempunyai relasi dengan database yang didesain.

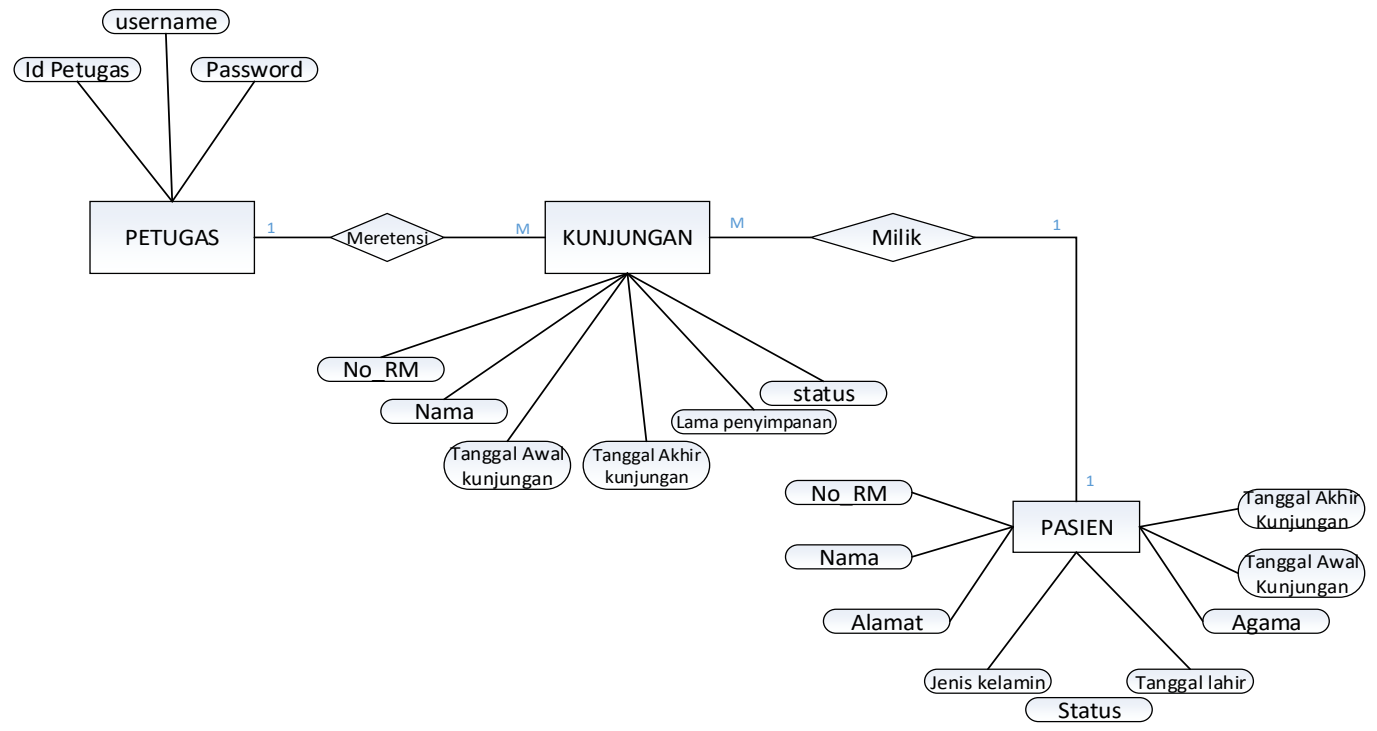

Gambar 8. Rancangan ERD

\section{B. Skema Relasi Tabel}

Skema relasi merupakan sebuah cara untuk merepresentasikan hubungan antara satu tabel dengan tabel lainnya melalui sebuah kolom kunci.

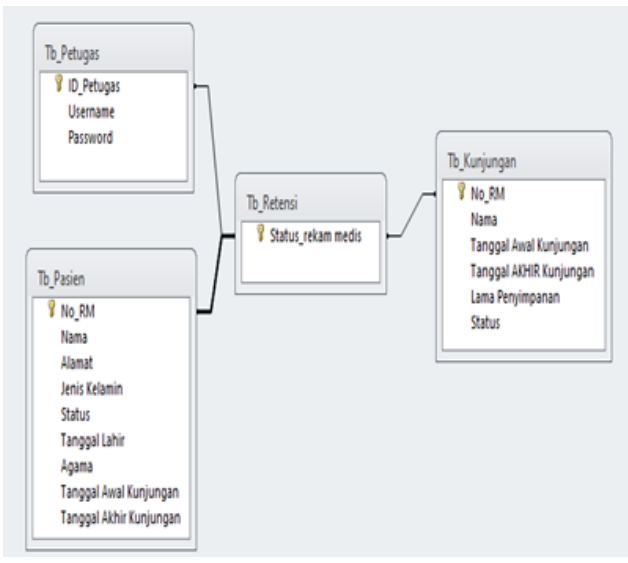

Gambar 9. Rancangan Skema Relasi Tabel yang diusulkan

\section{HASIL DAN PEMBAHASAN}

Perancangan sistem informasi retensi berkas rekam medis ini dengan menggunakan sistem yang sudah terkomputerisasi sehingga retensi bisa berjalan lebih efektif dan efesien. perancangan dari prosedur perancangan sistem informasi retensi di RSIA X menggunakan Microsoft visual studio 2010 akan diusulkan dalam bentuk Flowmap, Diagram Konteks, DFD (Data Flow Diagram), dan ERD (EntityRelationship Diagram). 
Berdasarkan hasil penelitian dan Analisa di RSIA X ada beberapa hal yang kurang dalam pelaksanaan Retensi di RSIA X yaitu belum adanya sistem informasi berupa Program atau Aplikasi Retensi berkas Rekam Medis.

Jadi pelaksanaan Retensi di RSIA X masih menggunakan Microsoft Excel dan dengan cara memeriksa satu persatu Berkas Rekam Medis berbasis kertas lalu menginput data secara manual ke Microsoft Excel, pengolahan data dan pembuatan laporan dilakukan secara manual serta informasi yang dihasilkan tidak lengkap sehingga terjadi kesulitan bagi petugas untuk memberikan pelayanan yang efektif dan efisien kepada pasien (Rohman, 2019) dan juga menyebutkan bahwa keterlambatan retensi juga didasari karena tidak adanya jadwal retensi sehingga petugas tidak tahu kapan harus melakukan retensi. (Marsum, Windari, Subinarto, \& Candra, 2018) Karena belum adanya sistem Retensi maka perekam medis membutuhkan waktu yang cukup lama untuk pengerjaan Retensi, maka dari itu penulis memberikan beberapa masukan dengan membuat Perancangan Sistem Informasi Retensi Rekam Medis di RSIA X dan

\subsection{Analisis Sistem}

sistem ini dapat membuat pengerjaan menjadi lebih Efektif.

\subsection{Rancangan yang diusulkan}

\section{Implementasi Dialog Layar}

1. Tampilan Layar Menu Utama

Tampi Tampilan Menu utama merupakan interface yang menampilkan beberapa menu diantaranya, menu Daftar User, Login, Data pasien, Data kunjungan, Data Retensi dan menu untuk menampilkan Laporan Data Retensi.

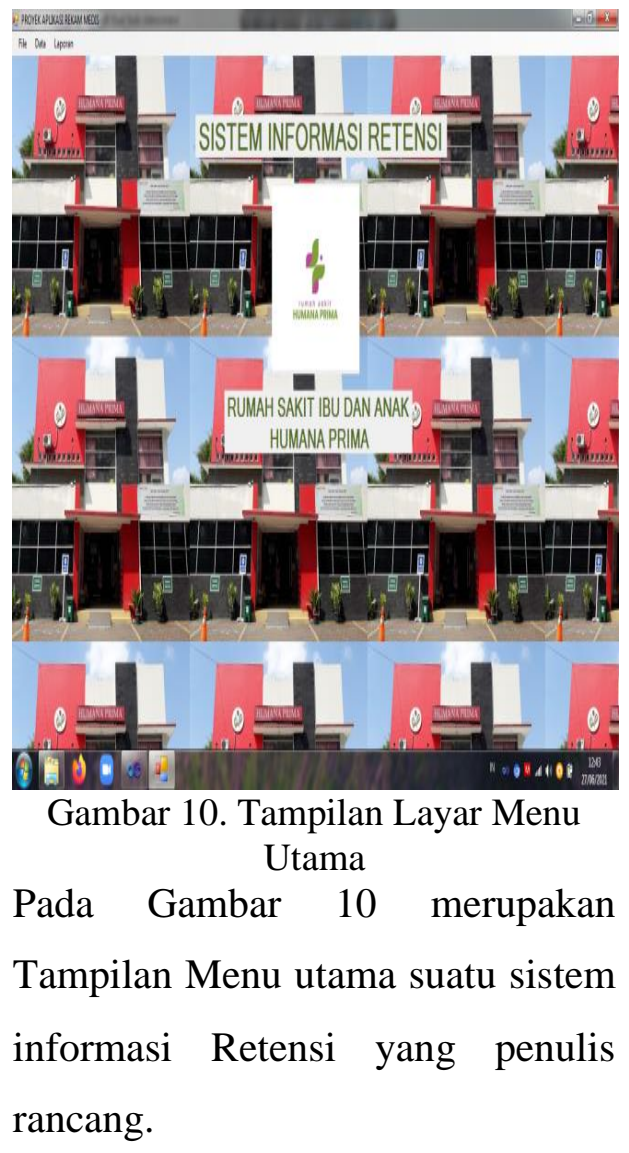


2. Tampilan Layar Menu Login

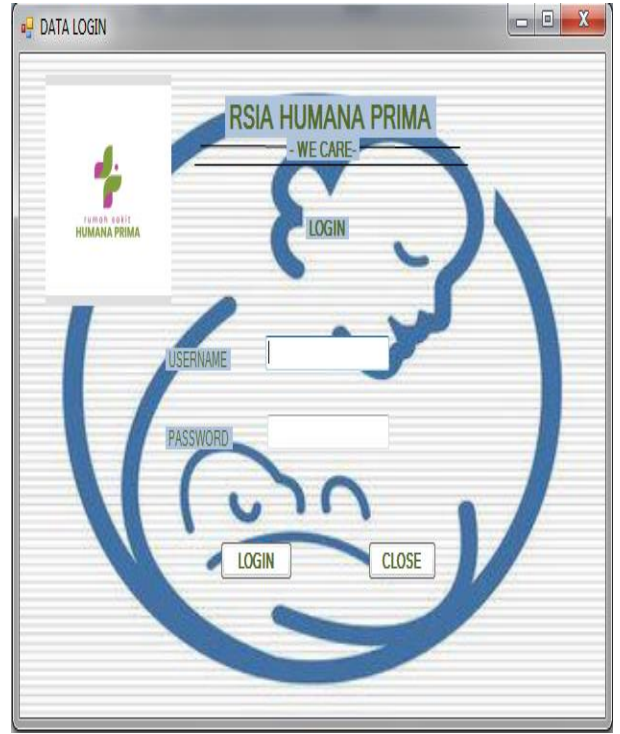

Gambar 11. Tampilan Layar Menu Login

Gambar 11 Merupakan Tampilan Menu Login untuk petugas yang mau mengakses masuk sistem ini.

3. Tampilkan Layar Form Daftar User

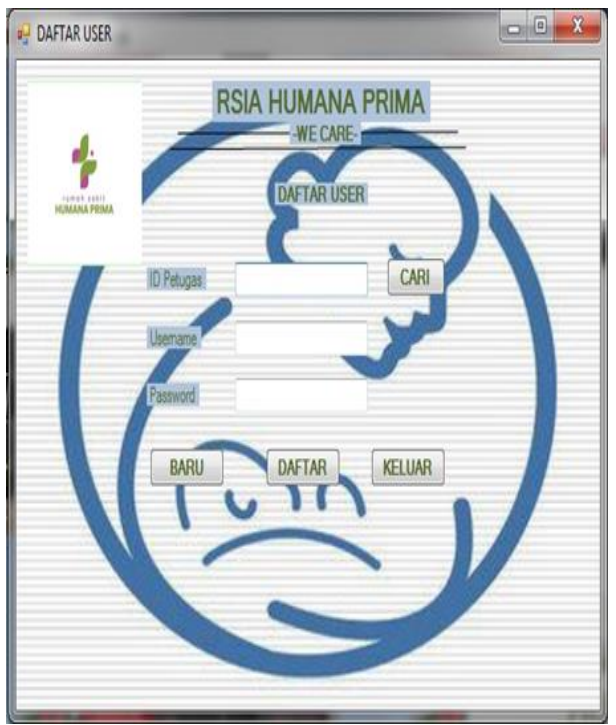

Gambar 12. Tampilan Layar Daftar User

Gambar 12 Merupakan Tampilan

Daftar User yang berisikan data Id,

Username dan password petugas untuk akun sistem yang dirancang.
4. Tampilkan layar Form Data Pasien

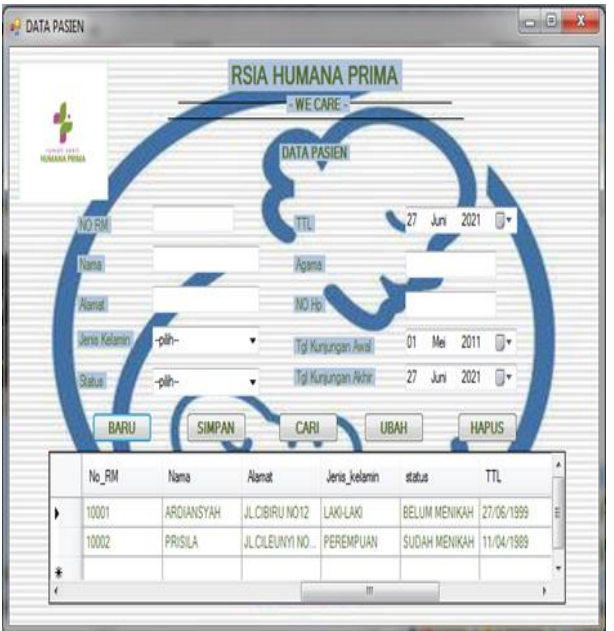

Gambar 13. Tampilan Layar Data Pasien

Gambar 13 Merupakan Tampilan Form Data Pasien untuk Melihat data Rekam medis pasien.

5. Tampilan Layar Form Data Kunjungan

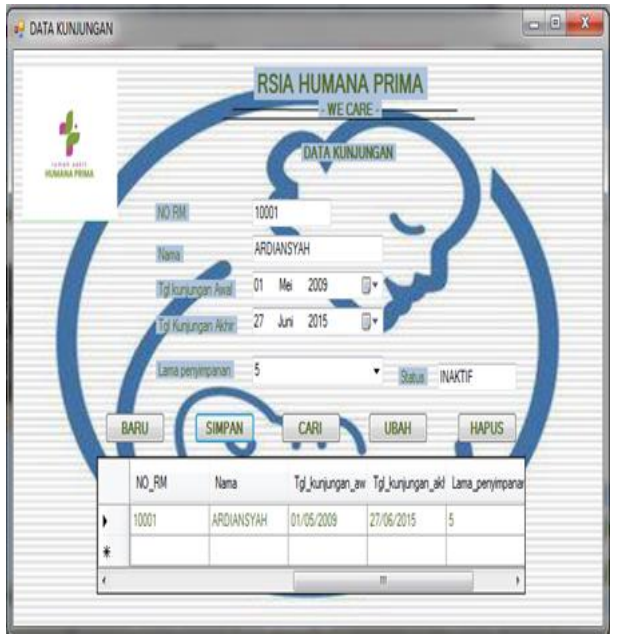

Gambar 14. Tampilan Layar Data Kunjungan

Gambar 14 Merupakan Tampilan Data kunjungan Pasien supaya mengetahui tanggal pasien awal kunjungan sampai dengan terakhir tanggal kunjungan pasien. 
6. Tampilkan Layar Form Data Retens

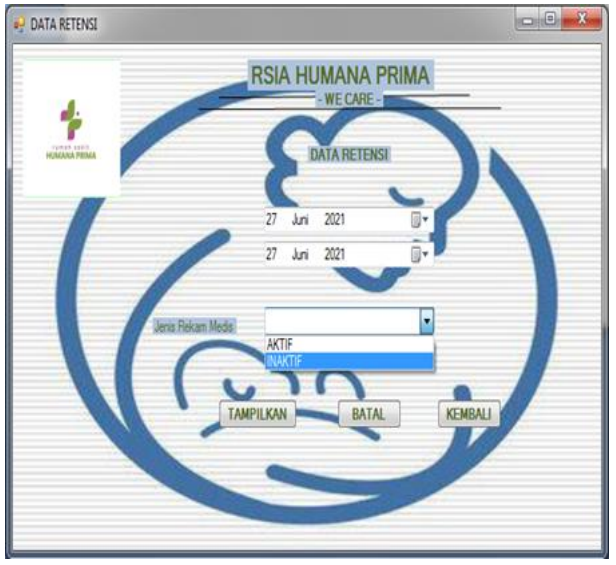

Gambar 15. Tampilan Layar Data Retensi

Gambar 15 Merupakan Tampilan

Data Retensi jadi memasukan tanggal data yang akan di Retensi nanti muncul data itu apakah masih Aktif atau InAktif.

7. Tampilan Layar Form Laporan Retensi Rekam medis

\begin{tabular}{|c|c|c|c|c|c|}
\hline \multirow{2}{*}{ No RII } & \multicolumn{5}{|c|}{ 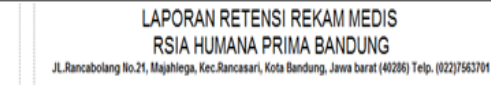 } \\
\hline & Nama & Tgl Kunjungan Awal & Il Kunjungan Akhit & Lama Penyimpanan & Status \\
\hline 10001 & ARDANSYAAH & $01.05-2009$ & $11-04-2014$ & 5 TAHUN & NONAKTE \\
\hline 10002 & PRISLA & 010522009 & 20042014 & 5 TAHUN & NOWAKT: \\
\hline 10012 & RMIGGAH & 01052009 & 21042014 & 5 TAHUN & NolWhT \\
\hline 10013 & DCXYA & 01.0522009 & 20.042014 & 5 TAHUN & NOIAKTE \\
\hline 10014 & ROSAUMAA & 01.052009 & $29-04-2014$ & 5 TAHUN & NOWAKT: \\
\hline 10021 & UUTFIM & 01.0522009 & $03.05-2014$ & 5 TAHUN & NOHAKT: \\
\hline 10023 & NGANP & 01052009 & 100552014 & 5 TAHUN & NOWhTs \\
\hline 10026 & ERI KARTOLO & 01.0522009 & 120.552014 & 5 TAHUN & NOWAKT \\
\hline 10027 & FAPHANA & 01.052009 & $20.052-2014$ & 5 TAHUN & NOHAKTS \\
\hline 10028 & FAllAH & 01.55 .2009 & 120662014 & 5 TAHUN & NOWAKT: \\
\hline 10029 & NURMAWA & 01.052009 & $22.06 \cdot 2014$ & 5 TAHUN & Nolwher \\
\hline 10031 & NENDENAPFl. & 01.052009 & $25.06-2014$ & 5TAHUN & NOWAKT \\
\hline 10032 & SYFAHW & 01.0522009 & 26-07.2014 & 5 TAHUN & NONAKTS \\
\hline 10033 & TARAZLA & 01052009 & 28007.2014 & 5 TAHUN & NOWAKT: \\
\hline 10048 & EKAYU & 02.052 .2009 & 01082014 & 5TAHUN & NOWAKn \\
\hline 10052 & SEPTANA & 02.0520009 & 150082014 & STAHUN & NOIAKTS \\
\hline
\end{tabular}

Gambar 16. Tampilan Layar Form

Laporan Retensi Rekam Medis

Gambar 16 ini merupakan Tampilan akhir atau laporan Retensi Rekam medis berkas Rekam Medis yang sudah tidak Aktif.
8. Tampilan Layar Form Laporan

Retensi Rekam medis

\begin{tabular}{|c|c|c|c|c|c|}
\hline \multirow{2}{*}{ 아요 } & \multicolumn{5}{|c|}{ 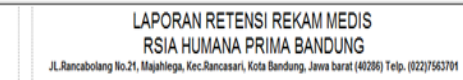 } \\
\hline & Nama & Tgl Kunjungan Awal & gl Kunjungan Akhit & Lama Penyimpanan & Status \\
\hline 10001 & AROANSYAH & 01.052009 & 1100.2014 & 5TAHUN & NOIWKTF \\
\hline 10002 & PRISLA & 010522009 & 20.042014 & 5 TAHUN & NOWWKTF \\
\hline 10012 & RAIGGAH & 010522009 & 21042014 & 5 TAHUN & Nowakth \\
\hline 10013 & DCOYA & 010.522009 & 20.042014 & STAHUN & NolWKTF \\
\hline 10014 & ROSAUMAA & 01.0522009 & 20.020 .2014 & 5 TAHUN & NOIWKTF \\
\hline 10021 & UUFIM & 01.0522009 & 03.052014 & 5 TAHUN & NOIWKTF \\
\hline 10023 & MGANP & 01.052009 & 100552014 & 5TAHUN & NOWWTR \\
\hline 10026 & ENIKARTOLO & 01.0522009 & 120.52 .2014 & STAHUN & NOWWKTF \\
\hline 10027 & FARHANA & 01.052009 & 20.052014 & 5TAHUN & NOWWKTF \\
\hline 10028 & FAUWAH & 01.052009 & $1206-2014$ & 5 TAHUN & NolWkTr \\
\hline 10229 & NUPMAWA & 010622009 & 20.062014 & STAHUN & NOWWKTF \\
\hline 10031 & IENDEN APFR & 01.052009 & 25062014 & 5TAHUN & NolWhif \\
\hline 10032 & SYFAHW & 01.052009 & 26.772014 & 5 TAHUN & NOWWKTF \\
\hline 10033 & TARAZAL & 010.522009 & 28.07 .2014 & 5TAHUN & NOWWKTF \\
\hline 10048 & EKAYU & 02.052009 & 01082014 & 5 TAHUN & NowkTF \\
\hline 10052 & SEPRANA & 02.622009 & 15002014 & 5TAHUN & NOIWKTF \\
\hline
\end{tabular}

Gambar 16. Tampilan Layar Form

Laporan Retensi Rekam Medis

Gambar 16 ini merupakan Tampilan akhir atau laporan Retensi Rekam medis berkas Rekam Medis yang sudah tidak Aktif.

9. Tampilan Layar Form Laporan Rekam Medis Aktif

\begin{tabular}{|c|c|c|c|c|c|}
\hline \multirow{2}{*}{ No RII } & \multicolumn{5}{|c|}{ 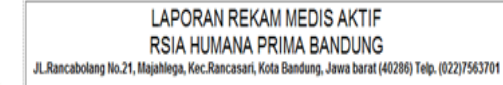 } \\
\hline & Nama & Tgl Kunjungan Awal & Tgl Kunjungan Akhit & Lama Penyimpanan & Status \\
\hline 301001 & FAUZZ AKBARR & $02 \cdot 0122020$ & 13.062020 & SBUANI & AKTF \\
\hline 301002 & KHLDA SFA & 02.012020 & 200662220 & 5BUAN & AKTF \\
\hline 301003 & RESTYA & $02 \cdot 012020$ & 2.082020 & 7BUAN & AKTF \\
\hline 301004 & INORAK & 02.0122020 & 05.012021 & 1TAHUN & AKTF \\
\hline 301005 & AWWARZ & $02 \cdot 0122020$ & $07 \cdot 10222020$ & 9BUAN & AKTF \\
\hline 301006 & SOPHA ZAHRA & $02 \cdot 012020$ & 10.0322021 & 1TAHUN & AKTF \\
\hline 301007 & INSAWH & $02 \cdot 0122020$ & 060022020 & 1GUAN & AKTF \\
\hline 3010008 & OPI SUHAAN & $02 \cdot 0122020$ & $12: 1222020$ & 11BUAN & AKTF \\
\hline 301009 & REON RAHMAN & 02.0122020 & $16 \cdot 12202020$ & 11BULN & AKTF \\
\hline 301010 & DBAHADAM & $02: 012020$ & 02.032021 & 1TAHUN & AKTF \\
\hline 301011 & A SAMT AZHAR & 02.012020 & 240720200 & 6BUANI & AKTF \\
\hline 301012 & WWINOAH & $02 \cdot 012020$ & 29.042021 & 3BUAN & AKTF \\
\hline 301013 & TEN WAHY & $02 \cdot 012020$ & 10.0522021 & 1TAHUN & AKTF \\
\hline 301014 & RFFUA AROI & $02 \cdot 0122020$ & 1109822020 & BBUANI & AKTF \\
\hline 301015 & LAVA ANDON & $02 \cdot 012020$ & $20 \cdot 122020$ & 1TAHUN & AKTF \\
\hline 301016 & EGA SLVVA & 02.012020 & 01.012021 & 1TAHUN & AKTF \\
\hline
\end{tabular}

Gambar 17. Tampilan Layar Form Laporan Rekam Medis Aktif

Gambar 17 Merupakan Tampilan Laporan Retensi Berkas Rekam Medis yang masih Aktif. 
10. Tampilan Layar Form Laporan Rekam medis Keseluruhan

\begin{tabular}{|c|c|c|c|c|c|c|}
\hline & \multicolumn{6}{|c|}{ 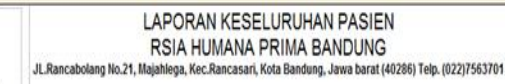 } \\
\hline NO RMA & Nama & Alamat & Jeats Kelammin & Status & $\pi L$ & Agama \\
\hline 101001 & DWN PELANGI & JaEum & PERENPUNN & MENKAH & $09.03-1998$ & ISLAM \\
\hline 101002 & AUIS SAUI & U CBRI & PEREMPUAN & BELUM MENKAH & 10.0122001 & ISLAM \\
\hline 101003 & SHIITA ONU & JLMARGAHA & PEREMPUAN & BELUM MENKAH & 23007.1998 & ISLAM \\
\hline 101004 & HASBIADAM & JLOGAM & LAKLAK & BELUM MENKAH & 07.082008 & ISLAM \\
\hline 101005 & HASIMARAFFA & USLUWANGI & PEREMPUAN & BELUM MENKAH & 15012:2005 & ISLAM \\
\hline 101006 & HAKM ALAM & I CONUNGK & LANUAK & BELUM MENKAH & 23.01.1999 & ISLAM \\
\hline 101007 & SEU SAFR & ILCWASTRA & PEREMPUAN & MENKAH & $05.01 \cdot 1980$ & ISLM \\
\hline 101008 & SISCA ANI & U GATSU & PEREMPUAN & MENKAH & 09.09-1991 & KRSTEN \\
\hline 101009 & FITRARAMA & ICGBRU & LAKLLAN & MENIKAH & 13.7.7.991 & ISLAM \\
\hline 101010 & ZAMZAM B & JLOGAM & LAKLLAK & BELUM NENKKAH & 17.07-1999 & ISLAM \\
\hline 101011 & ALBAN & ICBRU & LANLAND & MENKAH & $29 \cdot 92.1988$ & ISLAM \\
\hline 10012 & RAHMANR & JLMARGAHA & LAVLLAK & BELUM MENKAH & $0501-1999$ & ISLM \\
\hline 101013 & SANOKAN & JLMARGAHA & LAWLLAK & MENKAH & 19.06-1987 & ISLAM \\
\hline 101014 & WAHDAS & ICBRU & LAKLLAKD & MENKAH & 23-09-1992 & ISLAM \\
\hline 101015 & DNAR NDRI & J CBBRU & PEREMPUAN & BELUM MENKAH & 160062002 & ISLAM \\
\hline
\end{tabular}

Gambar 18. Tampilan Layar Form Laporan Rekam Medis Keseluruhan

Gambar 18 Merupakan Tampilan Form Laporan Rekam medis keseluruhan jadi menampilkan data keseluruhan pasien yg berkunjung.

\section{SIMPULAN}

Proses pelaksanaan Retensi Rekam medis di RSIA X masih manual menggunakan Microsoft Excel sehingga pengelolaan data Rekam medis yang Aktif dan InAktif susah untuk dilakukan, proses yang masih manual menyulitkan petugas untuk mencari data Rekam Medis yang Masih Aktif dan InAktif. Berdasarkan permasalahan diatas penulis memberikan saran untuk memperbaiki kinerja Instansi Rekam medis agar pelaksanaan retensi dapat berjalan dengan cepat, tepat dan akurat sehingga pelayanan Rekam medis bisa berjalan Optimal, Maka dari itu perlu adanya Teknologi Sistem Informasi.

Dari masalah di atas penulis merancang Sistem informasi Retensi Rekam Medis di RSIA $X$ berbasis Desktop menggunakan Microsoft Visual Studio 2010 dengan Microsoft Office Acces 2007 sebagai Database.

\section{DAFTAR PUSTAKA}

Erawantini. (2017). Pendidikan dan Pelatihan pada petugas rekam medis sebagai persiapan menjadi Clinical Instructure(CL) di puskesmas. Dalam Seminar Nasional Hasil Pengabdian Kepada Masyarakat, ISBN : 978602-14917-4-4.

Farlinda. (2019). Pembuatan Aplikasi Filling Rekam Medis Rumah sakit. Jurnal Kesehatan, 8-13.

Hariyanti. (2018). Analisis Penyebaba tidak terlaksananya Retensi dan Pemusnahan Berkas Rekam medis di Rumah sakit Daerah Kalisat Jember. Jember: Politeknik Negeri Jember.

Marsum, M., Windari, A., Subinarto, S., \& Candra, N. (2018). Tinjauan keterlambatan Retensi dokumen Rekam medis di RSUD DR.Soediran mangun sumarso kabupaten wonogiri. Jurnal Rekam Medis Dan Informasi Kesehatan.

PERMENKES. (2008). NO.269/Menkes/Per/III/2008

Pengertian Rekam Medis.

Pressman. (2015). Rekayasa perangkat lunak: Pendekatan Praktisi Buku I. Yogyakarta: Andi Publisher. 
Rohman. (2019). Sistem informasi Manajemen Rawat jalan di Klinik Pratama. Jurnal Informatika dan Rekayasa Perangkat Lunak, 115123.

Saraswati, D. (2015). Tinjauan pelaksanaan Retensi dokumen Rekam Medis dibagian Filling. UDINus Repository.

Sudirahayu, I. a. (2016). Rekam medis elektronik menggunakan DOQ-IT. Journal of Information Systems For Publis Health, 1.

Sugiyono. (2018). Metode Penelitian Pendidikan. Bandung: Alfabeta. 